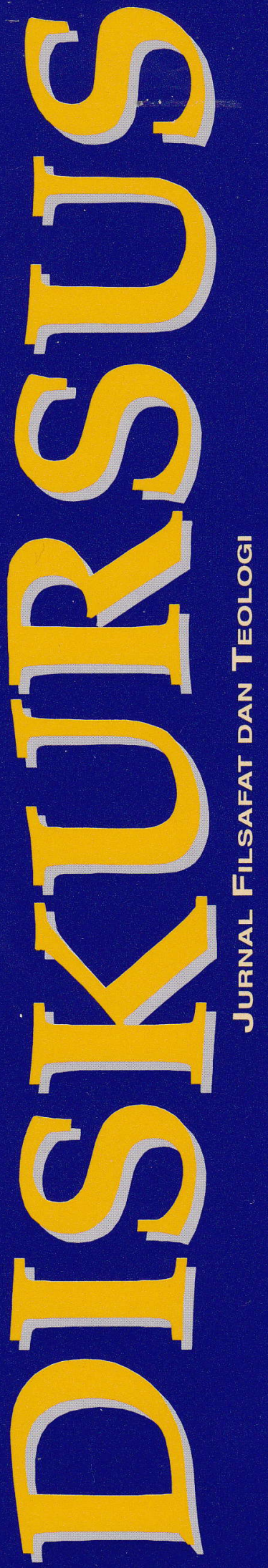

Joas Adiprasetya

Alasdair Macintyre and Martha Nussbaum on Virtue Ethics

Adrianus Sunarko

Berteologi bagi Agama di Zaman Post-Sekular

Yahya Wijaya

Doktrin Trinitas dalam Diskursus Teologi

Ekonomik

Martinus Ariya Seta

Status Tuhan dalam Filsafat Teoretis

Immanuel Kant

Tinjauan Buku

Diterbitkan oleh

PUSAT PENELITIAN FILSAFAT DAN TEOLOGI Sekolah Tingei Filsafat Driyarkara 


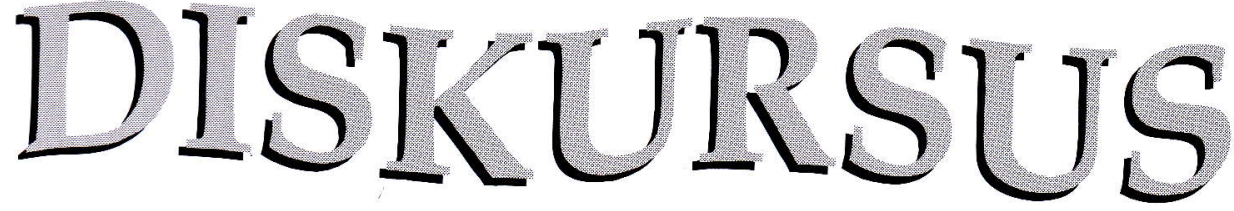

Jurnal Filsafat dan TeOlogI

Diskursus adalah jurnal ilmiah Filsafat dan Teologi serta IImu Pengetahuan yang berhubungan dengan kedua ilmu tersebut, yang diterbitkan oleh Pusat Penelitian Filsafat dan Teologi, Sekolah Tinggi Filsafat Driyarkara, Jakarta. Diskursus bertujuan memberikan dan menyampaikan sumbangan pemikiran filosofis dan teologis yang otentik, analitis dan kritis kepada para akademisi yang berminat pada llmu Filsafat dan IImu Teologi.

\begin{tabular}{|c|c|c|}
\hline \multirow[t]{5}{*}{ DEWAN REDAKSI } & & \\
\hline & KetUA & A. Setyo Wibowo \\
\hline & WAKIL KetUa & J. Sudarminta \\
\hline & ANGGOTA & $\begin{array}{l}\text { A. Eddy Kristiyanto, M. Sastrapratedja, } \\
\text { Simon P. Lili Tjahjadi }\end{array}$ \\
\hline & Redaktur Pelaksana & Thomas Hidya Tjaya \\
\hline \multicolumn{3}{|l|}{ ALAMAT REDAKSI } \\
\hline \multirow[t]{2}{*}{ \& TATA UsAHA } & \multicolumn{2}{|c|}{ Pusat Penelitian Filsafat dan Teolog } \\
\hline & \multicolumn{2}{|c|}{$\begin{array}{l}\text { Sekolah Tinggi Filsafat Driyarkara, } \\
\text { Cempaka Putih Indah } 100 \mathrm{~A} \text {, Jembatan Serong, Rawasari, } \\
\text { Jakarta 10520, Indonesia }\end{array}$} \\
\hline Telepon & \multicolumn{2}{|c|}{ (021) 4247129 • Fax: (021) 4224866} \\
\hline E-mail & \multicolumn{2}{|c|}{ jsd@dnet.net.id; administrasi@diskursus.com; redaksi@diskursus.c } \\
\hline Website & \multicolumn{2}{|l|}{ www.diskursus.com } \\
\hline Sekretaris & \multicolumn{2}{|c|}{ Yosephine Vera Paskariny } \\
\hline $\begin{array}{r}\text { Bank-Account } \\
\text { (BARU) }\end{array}$ & \multicolumn{2}{|c|}{$\begin{array}{l}\text { BCA - KCP Cempaka Puth Raya, Jakarta; No.AC: } 7060 \text { - } 461788 \\
\text { a.n.: YAY PENDIDIKAN DRIYARKARA }\end{array}$} \\
\hline
\end{tabular}

- Diskursus terbit 2 kali setahun (April \& Oktober) dan terbit untuk pertama kalinya April 2002.

- Isi artikel tidak mencerminkan pandangan staf redaksi. 


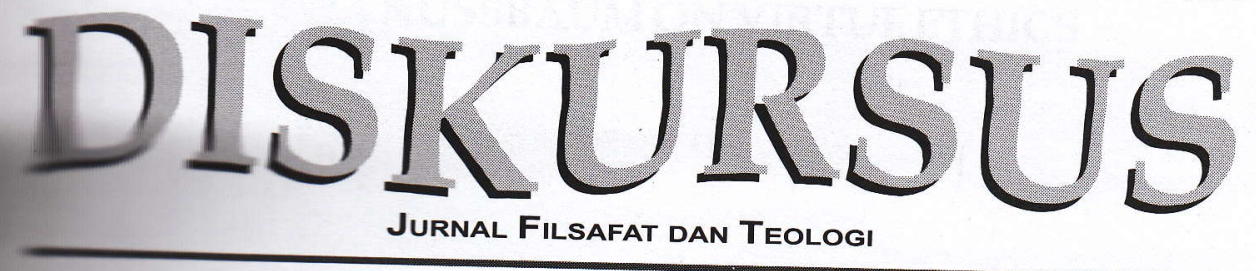

\section{DAFTAR ISI}

Alasdair Macintyre and Martha Nussbaum on Virtue Ethics JoAs ADIPRASETYA

Berteologi bagi Agama di Zaman Post-Sekular

ADRIANUS SUNARKO

Doktrin Trinitas dalam Diskursus Teologi Ekonomik

YAHYA WIJAYA

Status Tuhan dalam Filsafat Teoretis Immanuel Kant

Martinus Ariya Seta

Tinjauan Buku

Indeks Penulis

Mitra Bebestari

\section{Berdasarkan SK Direktur Jenderal Pendidikan Tinggi,}

Kementerian Pendidikan dan Kebudayaan Republik Indonesia

No. 56/DIKTI/Kep/2012 tanggal 24 Juli 2012 ,

Terbitan Berkala IImiah DISIUULSUS ditetapkan sebagai

Terbitan Berkala IImiah TERAKREDITASI sampai dengan 24 Juli 2017. 


\title{
STATUS TUHAN DALAM FILSAFAT TEORETIS IMMANUEL KANT
}

\author{
Martinus Ariya Seta
}

Abstrak: Di dalam filsafat teoretis Kant, status Tuhan bukan lagi transenden tetapi transendental. Perubahan status Tuhan menjadi transendental memiliki dampak ganda. Di satu sisi, Kant memberikan pendasaran rasionalitas konsep Tuhan. Akan tetapi di sisi lain, Kant menghindari penegasan terhadap eksistensi Tuhan. Menurut Kant, konsep Tuhan adalah sebuah ide regulatif. Ide regulatif tidak memiliki referensi di luar pikiran manusia. Kant hanya menegaskan urgensi logis konsep Tuhan bagi kesatuan pengetahuan. Akan tetapi, urgensi logis tidak cukup memadai sebagai argumen pembuktian eksistensi Tuhan. Kant memisahkan antara keternalaran dan ada. Pemisahan ini terlihat jelas di dalam kritik Kant terhadap pembuktian ontologis. Menurut penulis, profil filsafat transendental menjadi transparan di dalam kritik Kant terhadap pembuktian ontologis. Pengadopsian secara parsial paham dasar rasionalisme dan empirisme melatarbelakangi filsafat transendental dan memicu pemisahan antara keternalaran dan ada yang tampak jelas di dalam kritik Kant terhadap pembuktian ontologis.

Kata-kata kunci: Konsep, transendental, keternalaran, ada, ide regulatif, pembuktian ontologis

Abstract: In Kant's theoretical philosophy, the status of God is not transcendent anymore, but transcendental. The transcendental status of God has a double impact. On the one hand, the concept of God is conceivable. But on the other hand, Kant avoids the affirmation of the existence of God. The conceivability of God is not an argument for God's existence because the concept of God is a regulative idea. A regulative idea has no reference outside the mind. Kant only affirms the logical necessity of the concept of God. However, the logical necessity is not an

* Martinus Ariya Seta, Program Studi Pendidikan Agama Katolik (PAK), Fakultas Keguruan dan Ilmu Pendidikan, Universitas Sanata Dharma, Jl. Ahmad Jazuli 2, Yogyakarta 55002.E-mail: aseta81@gmx.at. 
adequate argument for the existence of God. Kant separates between conceivability and being. The separation is obvious in his critique toward the ontological argument. In my opinion, the profile of the transcendental philosophy is transparent in Kant's critique toward the ontological argument. The partial adoption of empirical and rational principles works behind the transcendental philosophy and leads to the separation between conceivability and being, which is visible in the Kant's critique toward the ontological argument.

Keywords: Concept, transcendental, conceivability, being, regulative idea, ontological argument.

\section{PENDAHULUAN}

Filsafat transendental yang dicetuskan oleh Immanuel Kant merupakan salah satu acuan pokok dari para kritikus agama modern maupun kontemporer. Teori proyeksi Feuerbach sebenarnya merupakan kelanjutan dari pendekatan filsafat transendental Kant di dalam mendekati persoalan Ketuhanan. ${ }^{1}$ Dalam teori proyeksi Feuerbach, sosok Tuhan tidak lagi dilihat sebagai obyek yang berada di luar pikiran manusia tetapi sosok yang dikonstruksikan oleh pikiran manusia dan status sosok tersebut tidak lagi bersifat ilahi tetapi manusiawi. Proses pengalihan status Tuhan dari obyek yang berada di luar pikiran manusia menjadi sosok yang dikonstruksikan di dalam pikiran manusia sudah dirintis oleh Immanuel Kant di dalam karyanya Kritik der reinen Vernunft (KrV). Teori proyeksi Feuerbach hanya meradikalisasi proses pengalihan tersebut.

Tulisan ini dimaksudkan untuk mengelaborasi proses pengalihan status Tuhan di dalam $\mathrm{KrV}$. Penulis akan menunjukkan titik-titik krusial dari pendekatan filsafat Ketuhanan Kant. Titik-titik krusial yang akan ditelaah adalah kritik pembuktian ontologis, konsep ada (Sein) dan keternalaran (Denken). Penulis melihat bahwa profil filsafat transenden-

1 Feuerbach lebih dikenal sebagai seorang Hegelian kiri dan bukan seorang Kantian Meskipun demikian, pengaruh pemikiran Kant di dalam pemikiran Feuerbach dapat ditelusuri di dalam teori proyeksi. 
tal Kant menjadi transparan di dalam kritik Kant terhadap pembuktian ontologis yang diulas dengan panjang lebar di dalam $\mathrm{KrV}$. Untuk dapat memahami kritik Kant terhadap pembuktian ontologis, konsteks sejarah perkembangan filsafat di dalam era Kant harus diperhatikan. Pemikiran Kant muncul di tengah ketegangan antara rasionalisme dan empirisme. Filsafat transendental Kant berada di bawah tarik ulur kedua aliran tersebut. Oleh karena itu, profil filsafat Kant di dalam $\mathrm{KrV}$ dan khususnya filsafat Ketuhanan harus dilihat sebagai kontinuitas dan diskontinuitas terhadap kedua aliran filsafat tersebut.

Secara sistematis, filsafat Kant dikategorikan ke dalam filsafat teoretis dan filsafat praktis. Kant juga menguraikan persoalan Ketuhanan di dalam filsafat praktis. $\mathrm{KrV}$ memuat pemikiran Kant akan persoalan Ketuhanan baik dalam ranah filsafat teoretis maupun filsafat praktis. Pada tulisan ini penulis hanya membatasi pembahasan pada filsafat teoretis di dalam $\mathrm{KrV}$.

\section{FILSAFAT TRANSENDENTAL SEBAGAI UPAYA HARMONISASI EMPIRISME DAN RASIONALISME}

Filsafat transendental yang ditawarkan oleh Kant dilatarbelakangi oleh pertikaian antara aliran empirisme dan rasionalisme. Pertikaian antara kedua aliran ini terfokus pada tema metafisika. Kant melabeli para pemikir aliran empirisme sebagai kaum "skeptis" sedangkan para pemikir aliran rasionalisme sebagai kaum "dogmatis." ${ }^{2}$ Empirisme menolak keberadaan metafisika sedangkan rasionalisme membela keberadaan metafisika. Pertikaian antara empirisme dan rasionalisme adalah persoalan primat sifat a posteriori dari pengalaman inderawi atau sebaliknya primat sifat a priori dari akal budi (Verstand): "Yang membedakan antara rasionalisme dan empirisme adalah penekanan yang berbeda berkaitan dengan hubungan satu sama lain antara dua sumber pengetahuan," ${ }^{3}$

2 Immanuel Kant, Kritik der reinen Vernunft A X. Untuk selanjutnya, Kritik der reinen Vernunft akan disingkat $\mathrm{KrV}$ di dalam catatan kaki.

3 Gottfried Gabriel, Grundprobleme Erkenntnistheorie: Vom Descartes zu Wittgenstein (Paderborn: Schöningh, 2008), S. 29. 
yaitu antara pengalaman inderawi dengan akal budi. Pangkal pertikaian dari kedua aliran tersebut adalah persoalan primat. Oleh karena itu, perlu digarisbawahi bahwa rasionalisme tidak menolak sama sekali peran pengalaman inderawi dan empirisme juga tidak menolak sama sekali peranan akal budi.

Kant mencoba mencari jalan keluar dari pertikaian antara rasionalisme dan empirisme. Jalan keluar yang ditempuh oleh Kant adalah harmonisasi paham dasar empirisme maupun rasionalisme. Kant tidak menolak peran penting pengalaman inderawi sebagai salah satu elemen pembentuk pengetahuan. Akan tetapi, Kant juga menekankan keberadaan unsur pengetahuan "yang terlepas dari pengalalaman dan juga dari pencerapan inderawi" ${ }^{4}$ dan unsur ini bersifat a priori. Dari sisi empirisme, Kant mengamini bahwa status pengetahuan membutuhkan penegasan intuisi (Anschauung) dari pengalaman inderawi dan dari sisi rasionalisme, Kant mengamini bahwa pengetahuan juga dipengaruhi oleh faktor a priori. Faktor a priori inilah yang menjadikan sebuah pengetahuan dapat bersifat universal dan memiliki derajat keharusan. ${ }^{5}$ Harmonisasi yang dilakukan olah Kant berujung pada pengakuan akan "legitimasi dengan pembatasan"6 dari paham empirisme dan rasionalisme. Harmonisasi semacam ini merupakan pembatasan keberlakuan (Gültigkeit) dari paham dasar empirisme maupan rasionalisme. Dengan kata lain, harmonisasi yang dilakukan Kant adalah pengadopsian secara parsial kedua paham tersebut.

Bagaimana Kant mengharmonisasi paham empirisme dan rasionalisme? Sifat a posteriori dari pengalaman inderawi maupun sifat $a$ priori dari akal budi bersifat konstitutif terhadap pengetahuan dan Kant menekankan bahwa peran akal budi bersifat transendental. Yang dimaksud dengan sifat transendental adalah pengetahuan, yang hanya

\section{$4 \quad \mathrm{KrV}$ B 2.}

5 Lih. Johannes Hirschberger, Geschichte der Philosophie II: Neuzeit und Gegenwart (Freiburg: Herder, 1952), S. 256.

6 Otfried Höffe, Kants Kritik der reinen Vernunft: Die Grundlegung der modernen Philosophie, (München: C.H. Beck, 2011), S. 83. 
terarah bukan pada obyek tetapi pada modus pengetahuan yaitu pengetahuan "yang hanya terarah bukan kepada obyek tetapi kepada modus pengungkapan obyek, sejauh pengetahuan ini secara a priori dimungkinkan." Sifat transendental tidak berkaitan dengan obyek yang diketahui tetapi prasyarat a priori yang memungkinkan sebuah pengetahuan. Sifat transendental ini tidak melekat pada obyek tetapi pada subyek. ${ }^{8}$ Istilah subyek dalam pemikiran Kant tidak ada kaitannya dengan kesewenangwenangan ego. Dengan menggunakan istilah subyek, Kant ingin menunjukkan keterlibatan akal budi yang bersifat a priori dalam membentuk sebuah pengetahuan. Nuansa formal terlihat sangat kental di dalam filsafat transendental. Yang menjadi perhatian Kant adalah aspek quaestio iuris, bukan aspek quaestio facti. Kant lebih mempersoalkan peran subyek dalam menciptakan pengetahuan dan bukan obyek pada dirinya sendiri (das Ding an sich). Kant berusaha menggali peran unsur a priori yang melekat di dalam subyek dalam proses terjadinya sebuah penge-tahuan.

Bukan hanya subyek tetapi juga pengalaman inderawi juga bersifat konstitutif terhadap pengetahuan. Menurut Kant, pengetahuan terjadi ketika kategori-kategori dari akal budi yang bersifat a priori memperoleh padanannya di dalam pengalaman inderawi yang bersifat a posteriori. ${ }^{9}$ Pengalaman inderawi menjadi semacam tempat bereksperimen bagi akal budi yang bersifat a priori. Secara sistematis dapat dirumuskan bahwa pengetahuan harus memenuhi unsur formal dan unsur material. Akal budi dengan kategori-kategori yang bersifat a priori merupakan unsur formal dan pengalaman inderawi yang bersifat a posteriori merupakan unsur material. ${ }^{10}$

Lebih jauh, Kant menjelaskan relasi antara subyek dan obyek pengetahuan dengan sebuah hypothesis. Kant mengajukan hipotesis epistemologis bahwa akal budi tidak lagi mengarahkan diri kepada obyek

\footnotetext{
$7 \quad \mathrm{KrV}$ B 25.

8 Lih. Otfried Höffe, Kants Kritik der reinen Vernunft, S. 58.

$9 \mathrm{KrV}$ B XIII.

10 Lih. Karl Jasper, Die großen Philosophen (München-Zürich: Piper, 2012), S. 424.
} 
(Gegenstand) tetapi obyek mengarahkan diri kepada akal budi; Kant membandingkan hypothesis ini dengan revolusi Kopernikus. ${ }^{11}$ Baik Kant maupun Kopernikus mengajukan pembalikan cara berpikir. Akan tetapi jika dicermati, pembandingan hypothesis Kant dengan revolusi Kopernikus tidak sepenuhnya tepat karena hypothesis Kant menjadikan manusia berada di centrum sedangkan revolusi Kopernikus berimplikasi pada penggusuran manusia dari tempatnya di centrum. ${ }^{12}$

Apa implikasi dari hipotesis epistemologis yang digulirkan oleh Kant? Obyek harus mengarahkan diri kepada kategori-kategori a priori di dalam subyek. Pengetahuan akan sebuah obyek tidak dapat dilepaskan dari unsur a priori di dalam subyek. ${ }^{13}$ Bukan pengalaman inderawi yang mendikte akal budi yang dilekati dengan kategori-kategori yang bersifat a priori tetapi akal budi menyodorkan sebuah rancangan yang akhirnya harus diuji di dalam pengalaman inderawi. Dalam bahasa modern, teori pengetahuan Kant adalah konstruktivisme. Pengetahuan tidak lagi dipandang sebagai pencerminan kenyataan di dalam pikiran seperti yang dipahami dalam tradisi skolastik. Di dalam paham konstruktivisme, kenyataan bukan merupakan sesuatu yang terlepas dari pikiran manusia, melainkan ikut diciptakan oleh pikiran manusia. Kant melakukan sebuah pembalikan terhadap peran subyek. ${ }^{14}$ Dalam tradisi metafisika Aristoteles, subyek bersifat reseptif terhadap obyek sedangkan dalam filsafat transendental subyek justru bersifat sangat aktif terhadap obyek.

11 Lih. KrV B XVI.

12 Kant membandingkan hipotesisnya dengan revolusi Kopernikus untuk mengungkapkan sebuah pembalikan paradigma. Jika dicermati dengan lebih cermat, pembalikan paradigma yang dilakukan oleh Kant tidak dapat disamakan dengan pembalikan paradigma revolusi Kopernikus: "Kopernikus menolak penempatan manusia secara geografis pada posisi centrum, karena bumi bukanlah titik pusat dari kosmos... Sebaliknya Kant justru menggeser manusia pada posisi centrum." Otfried Höffe, Kants Kritik der reinen Vernunft, S. 49.

13 Lih. Gerd Irrlitz, Kant Handbuch: Leben und Werke (Stuttgart: J. B. Metzler, 2010), S. 188.

14 Lih. Horst Seidl, Sein und Bewusstsein: Erörterungen zur Erkenntnislehre und Metaphysik in einer Gegenüberstellung von Aristoteles und Kant (Hildesheim-Zürich-New York: Olms, 2001), S. 22. 


\section{THEOLOGIA TRANSCENDETALIS}

Apa jadinya jika apa yang secara a priori telah dirancang oleh akal budi tidak memiliki padanan di dalam pengalaman inderawi? Inilah yang menjadi persoalan metafisika khusus (metaphysica specialis). Dalam tradisi rasionalisme, persoalan metafisika dikategorikan ke dalam metafisika umum dan metafisika khusus. Metafisika khusus dibagi ke dalam tiga bidang, yaitu psychologia rationalis, cosmologia rationalis dan theologia transcendentalis. Kant masih mempertahankan sistematisasi metafisika khusus tersebut. ${ }^{15}$ Psychologia rationalis berbicara tentang tema roh. Cosmologia rationalis berbicara tentang tema dunia dan theologia transcendentalis tentang Tuhan. Tulisan ini hanya menyinggung tema theologia transcendentalis karena penulis ingin membatasi uraian pada persoalan Ketuhanan.

Istilah theologia dalam konteks metafisika khusus sebagaimana yang dipahami oleh Kant tidak berkaitan sama sekali dengan tema pewahyuan ilahi. Kant merumuskan theologia transcendentalis sebagai "ide kesatuan mutlak"16 sekaligus "prasyarat tertinggi dari kemungkinan akan semua yang dapat dipikirkan." 17 Fungsi theologia transcendentalis sebagai "kesatuan" dan "prasyarat" perlu mendapat sebuah penegasan baik sebagai bagian dari metafisika khusus.

Di dalam kata pengantar edisi pertama $\mathrm{KrV}$, Kant menyinggung persoalan dialektika di dalam metafisika khusus. Di manakah letak persoalan dialektika di dalam metafisika khusus? Di dalam kata pengantar $\mathrm{KrV}$ edisi pertama, Kant sudah menyinggung akan dialektika di dalam metafisika khusus. Pikiran manusia "dibebani dengan pertanyaanpertanyaan, yang tidak terbantahkan karena memang disodorkan sendiri oleh sifat hakiki dari nalar, tetapi nalar tidak dapat memberi jawaban karena pertanyaan-pertanyaan tersebut melampaui kemampuan nalar manusia."18 Pikiran manusia akhirnya harus berhadapan dengan per-

15 Lih. $K r V$ B 391-392.

$16 \mathrm{KrV}$ B 391.

$17 \mathrm{KrV}$ B 391.

$18 \mathrm{KrV}$ A VII. 
tanyaan-pertanyaan yang tidak lain adalah tiga tema metafisika khusus tanpa dapat menemukan jawaban. Secara khusus dalam theologia transcendentalis, pikiran manusia akan dihadapkan pada pertanyaan akan Tuhan. Tema-tema metafisika khusus bukanlah sebuah tema yang memiliki kaitan langsung dengan pengalaman inderawi. Sebagai sebuah ide, tema-tema metafisika khusus bersifat transendental. Tuhan sebagai tema theologia transcendentalis bukan lagi sebuah ide transendent tetapi ide transendental.

Kant secara khusus membedakan cara kerja pikiran manusia menjadi dua organ yaitu akal budi (Verstand) dan budi atau intellek (Vernunft). ${ }^{19}$ Akal budi berfungsi mengatur pengalaman inderawi untuk dijadikan pengetahuan. Intelek bekerja untuk menciptakan sebuah kesatuan sistematis dari pengetahuan dan intelek tidak menghasilkan sebuah ide yang merujuk pada obyek yang berada di luar pikiran manusia. Pembedaan antara intelek dan akal budi bukanlah pembedaan fisiologis tetapi lebih bersifat spekulatif filosofis. Ide transendental adalah "focus imaginarius"20 (baca: titik imajiner) yang diperlukan untuk menciptakan sebuah kesatuan akal budi. Ide transendental merupakan ide dalam ranah budi dan oleh karenanya tidak memiliki referensi di dalam pengalaman inderawi. Ketiadaan referensi di dalam pengalaman inderawi, menjadikan tema roh, dunia dan Tuhan bukan lagi sebagai sebuah obyek pengetahuan.

Persoalan dasar filsafat pengetahuan Kant adalah penyatuan dikotomi antara subyek dan non subyek. ${ }^{21}$ Unsur non subyek yang diserap oleh subyek melalui pengalaman inderawi merupakan sebuah stempel yang menegaskan eksistensi dari apa yang secara a priori melekat pada subyek. Dalam bahasa Kant "sebuah konsep yang tidak dibarengi dengan intuisi adalah kosong dan intuisi tanpa dilengkapi dengan kon-

19 Penerjemahan istilah Vernunft dan Verstand mengacu pada terjemahan dari Simon P.L. Tjahjadi. Lih. Simon P.L. Tjahjadi, Tuhan Para Filsuf dan Ilmuwan: Dari Descartes sampai Whitehead (Kanisius: Yogyakarta, 2007), hlm. 48.

$20 \mathrm{KrV} \mathrm{B} 672$.

21 Lih. Herbert Huber, "Kants Idealismus und dessen grundsätzliche Überwindung durch Hegel," Theologie und Philosophie 59 (1984), S. 39. 
sep adalah buta." ${ }^{22}$ Konsep melekat pada subyek dan intuisi merupakan data yang diserap dari unsur non subyek. Sebuah konsep yang tidak didukung dengan pengalaman inderawi yang diserap dari non subyek, tidak memiliki landasan kuat untuk dinyatakan eksistensinya.

Tuhan sebagai yang mutlak (Absolut) adalah ide transendental yang berfungsi untuk menciptakan kesatuan. Tuhan di dalam konteks theologia transendentalis sebagai sebuah pemikiran bukanlah sebuah menegas-

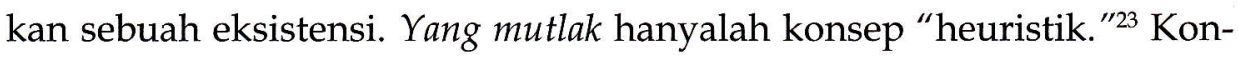
sep heuristik tidak menunjuk kepada eksistensi di luar subyek tetapi menunjukkan fungsinya di dalam rangka menciptakan sebuah kesatuan di dalam pengetahuan. Sifat heuristik sebuah konsep tidak memiliki intensionalitas dengan sesuatu di luar pikiran manusia.

Padanan kata dari konsep heuristik adalah ide regulatif. Yang mutlak sebagai ide transendental hanyalah sekedar ide regulatif bagi sebuah pengetahuan. Ide regulatif dipahami dalam perbedaannya dengan ide konstitutif Kant mengatakan bahwa "ide-ide transendental sama sekali bukan ide yang digunakan secara konstitutif." ${ }^{24}$ Sebaliknya, ide-ide transendental merupakan ide yang digunakan secara regulatif sebagai "sebuah keharusan yang tidak terelakkan," ${ }^{25}$ meskipun tidak memiliki intensionalitas di luar pikiran manusia. Intelek tidak bertugas untuk menata pengalaman inderawi tetapi menata akal budi demi terbentuknya sebuah kesatuan sistematis. Ide regulatif berfungsi untuk menciptakan kesatuan sistematis pengetahuan ini. Kesatuan sistematis dari ide regulatif "hanya sekedar proyeksi." ${ }^{26}$ Karena hanya sekedar proyeksi, ide regulatif "harus dilihat sebagai sebuah persoalan" 27 tanpa adanya sebuah jawaban dan penegasan eksistensi. Ini merupakan sebuah penegasan dari dialektika ide Tuhan di dalam metafisika khusus.

$22 \mathrm{KrVB} 75$.

23 Franz Schupp, Geschichte der Philosophie im Überblick, Bd.3: Neuzeit (Hamburg: Felix Meiner, 2003), S. 349.

$24 \mathrm{KrV}$ B 672.

$25 \mathrm{KrV}$ B 672.

$26 \mathrm{KrV}$ B 675.

$27 \mathrm{KrV}$ B 675 
Pembedaan antara ide regulatif dan ide konstitutif merupakan salah satu kunci di dalam memahami filsafat Ketuhanan di dalam $\mathrm{KrV}$. Kant memisahkan antara "menalar" (Denken) dengan "mengetahui" (Erkennen). ${ }^{28}$ Dapat dikatakan bahwa Kant membedakan antara memikirkan dengan mengenal. Tuhan sebagai yang mutlak hanya dapat dipikirkan atau dinalar tetapi tidak dapat dikenali atau diketahui. Yang mutlak adalah ide transendental dan ini bukanlah obyek dari pengetahuan; yang mutlak hanya merupakan sebuah ide regulatif dan bukan ide konstitutif; sebagai ide regulatif, yang mutlak bukanlah sebuah obyek yang berada di luar pikiran manusia. Ide regulatif merupakan ide budi sedangkan ide konstitutif merupakan ide akal budi. Ide budi (Vernunft) tidak menunjukkan sama sekali referensi terhadap suatu obyek di luar pikiran manusia. Ide budi tidak memiliki sifat "ostensif," ${ }^{29}$ sedangkan ide konstitutif berada di dalam ranah akal budi (Verstand) dan memiliki sifat ostensif.

Pemisahan antara menalar dengan mengenal memiliki korelasi dengan pembedaan antara ide regulatif dengan ide konstitutif. Ide regulatif merupakan sebuah ide yang hanya dapat dinalar atau dipikirkan tetapi tidak dikenal atau tidak diketahui. Istilah mengenal atau mengetahui berkaitan langsung dengan persoalan eksistensi. Dalam skema pemikiran Kant, sesuatu dapat dikenali atau diketahui jikalau sesuatu itu memiliki eksistensi. Ide regulatif tidak memiliki intensionalitas terhadap eksistensi obyek di luar pikiran manusia. Sebaliknya, ide konstitutif merupakan sebuah ide yang dilandasi pada pengenalan akan eksistensi.

Tuhan di dalam theologia transendentalis dipahami sebagai "Ideal." 30 Kant menggunakan istilah Ideal untuk menunjukkan semacam sebuah

28 Lih. Friedrich Kaulbach, Immanuel Kant (Berlin-New York: de Gruyter, 1982), S. 114.

29 Istilah ostensif merupakan kata serapan dari bahasa Latin. Kata ostendere dalam bahasa Latin berarti menunjukkan atau mengacu. Secara harafiah ostensif berarti bersifat menunjukkan. Franz Schupp menggunakan istilah ostensif sebagai antonim dari istilah heuristik. Sifat ostensif dari sebuah ide, konsep atau proposisi menunjukkan intensionalitas terhadap obyek di luar pikiran manusia. Sedangkan sifat heuristik menunjukkan aspek penyelidikan akan sebuah kesatuan dan bukan aspek intensionalitas. Franz Schupp, Geschichte der Philosophie im Überblick, S. 349.

$30 \mathrm{KrV}$ B 596. 
hirarki di dalam budi (Vernunft). Secara umum, tema-tema di dalam metafisika khusus berstatus sebagai ide. Kant secara khusus melabeli ide Tuhan dengan istilah Ideal di dalam theologia transcendentalis untuk membedakan dengan ide dalam ranah psychologia rationalis dan cosmologia rationalis. Ideal memiliki derajat abstraksi yang lebih tinggi dari ide. ${ }^{31}$ Status Ideal hanya melekat pada Tuhan sedangkan roh dan dunia hanya berstatus ide. Kant mendefinisikan Ideal sebagai ide yang "tidak hanya semata-mata konkret tetapa ada di dalam sosok individu"32 yang merupakan prototipe (Urbild) dan segala sesuatu merupakan turunan atau citra dari prototipe (Nachbild). Sebagai prototipe, Ideal dilekati dengan kesempurnaan dan sebuah kesempurnaan berakar dalam sosok yang bersifat personal. Dengan menggunakan istilah Ideal, Kant berusaha mengkaitkan dengan tradisi monotheistik Kristiani yang menempatkan Tuhan sebagai sosok personal. ${ }^{33}$ Kesempurnaan bukan hanya sekadar prinsip tetapi terwujud dalam sosok personal yang menjadi prototipe dari segala yang ada. Secara singkat dapat dikatakan bahwa ide merupakan prinsip sedangkan Ideal memiliki perwujudan yang bersifat personal. Kesempurnaan bukan hanya sekedar prinsip tetapi memiliki kongruensi di dalam sosok individu. Akar dari kesempurnaan bukanlah prinsip tetapi individu atau sosok personal. Perlu digarisbawahi bahwa Ideal bersifat transendental sehingga kongruensi antara ide dengan Ideal tidak berimplikasi pada sebuah pernyataan eksistensi. Kongruensi ini hanya bersifat "simbolis" 34 di dalam pikiran manusia tanpa ada intensionalitas dengan obyek di luar pikiran manusia. Kongruensi di dalam budi (Vernunft) tidak dapat dijadikan sebuah penegasan eksistensi.

Kant mengkaitkan konsep Ideal dengan konsep Tuhan sebagai "keseluruhan realitas" ${ }^{35}$ (omnitudo realitatis). Konsep omnitudo realitatis

31 Lih. $K r V$ B 596.

$32 \mathrm{KrV}$ B 596.

33 Lih. Giovanni Sala, Kant und die Frage nach Gott (Berlin-New York: de Gruyter 1990), S. 233.

34 Gerd Irrlitz, Kant Handbuch: Leben und Werk (Stuttgart: J.B, Metzler, 2010), S. 255.

$35 \mathrm{KrV}$ B 603. 
merupakan warisan dari rasionalisme yang digunakan untuk menjelaskan ketentuan (Bestimmung) dari segala sesuatu dengan melandaskan diri pada relasi yang bersifat negasi antara yang mutlak dengan yang nisbi. ${ }^{36}$ Secara filosofis, genesis dari yang nisbi tidak dapat dilepaskan dari yang mutlak. Yang nisbi merupakan negasi dari keseluruhan realitas (omnitudo realitatis) yang termuat di dalam yang mutlak sebagai prototipe. Pengaruh pemikiran Spinoza akan prinsip negasi yang melandasi ketentuan dari segala sesuatu. ${ }^{37}$ Ideal menjadi semacam substansi (substratum) yang memuat seluruh realitas. Segala kemungkinan predikat termuat di dalam substansi ini. Predikat yang melekati segala sesuatu yang tidak lain adalah turunan (derivatif) yang bersifat pembatasan (Einschränkung) dari omnitudo realitatis yang melekat pada yang mutlak. Yang nisbi tidak lain adalah negasi dari yang mutlak. Perlu digarisbawahi bahwa negasi ini bersifat parsial. Ketentuan yang melakat pada yang nisbi mewarisi sebagian dari ketentuan yang mutlak.

Pemahaman akan Tuhan sebagai Ideal Transendental tidak berimplikasi pada sebuah penegasan eksistensi. Kant tidak menolak pemikiran tentang Tuhan di dalam ranah teoretis. Bahkan, Kant memberikan sebuah landasan keternalaran (Denken). Kant tidak meragukan keternalaran Tuhan. Akan tetapi keternalaran tidaklah cukup untuk menegaskan eksistensi. Inilah yang menjadi salah satu pemikiran pokok filsafat Ketuhanan dari Immanuel Kant. Dari uraian di atas tadi, terlihat jelas pemisahan antara Ada (Sein) dan keternalaran (Denken) membebani cara berpikir Kant. Penolakan terhadap eksistensi Tuhan bukanlah konsekuensi logis dari filsafat Ketuhanan Immanuel Kant. Masih terbuka kemungkinan bahwa Tuhan ada, akan tetapi Kant membiarkan persoalan eksistensi Tuhan mengambang. ${ }^{38}$ Mengapa persoalan eksistensi Tuhan

36 Lih. Wolfgang Röd, Der Gott der reinen Vernunft: Ontologischer Gottesbeweis und rationalistische Philosophie (München: C.H. Beck, 2009), SS. 148-149.

37 Lih. Wolfgang Röd, Der Gott der reinen Vernunft, S. 148.

38 Lih. Friedo Ricken. "Von der Unentbehrlichkeit der transzendentalen Theologie: Zum Ideal der reinen Vernunft" in Kants Grundlegung einer kritischen Metaphysik: Eine Einführung in die Kritik der reinen Vernunft, ed. Norbert Fischer (Hamburg: Felix Meiner), S. 317. 
menjadi mengambang? Eksistensi Tuhan "tidak dapat dibuktikan, tetapi juga tidak dapat difalsifikasi." 39 Bagaimana Kant mengambangkan persoalan eksistensi Tuhan dapat ditelusuri lebih dalam lagi di dalam penolakan Kant terhadap pembuktian ontologis.

\section{KRITIK KANT TERHADAP PEMBUKTIAN ONTOLOGIS}

Pembuktian ontologis merupakan sebuah usaha untuk menunjukkan eksistensi Tuhan secara a priori. Pencetus pembuktian ontologis adalah Anselmus dari Canterbury. Pelabelan ontologis pada model pembuktian secara a priori tidak berasal dari Anselm, melainkan berasal dari Immanuel Kant. ${ }^{40}$ Kritik Kant terhadap pembuktian ontolologis sebenarnya tidak ditujukan kepada Anselmus tetapi kepada Descartes. ${ }^{41}$ Sebelum menyoroti kritik Kant terhadap pembuktian ontologis versi Descartes, penulis akan menjelaskan pembuktian ontologis versi Anselmus sebagai prototipe dari pembuktian ontologis versi Descartes.

Rumusan awal dari pembuktian ontologis adalah "aliquid quo nihil maius cogitari non possit." 42 Inilah adalah konsep Tuhan yang menjadi landasan dari pembuktian ontologis. Di dalam bahasa Indonesia, rumusan ini dapat diterjemahkan "sesuatu yang lebih besar daripadanya tidak dapat dipikirkan." 43 Tuhan adalah batas maximum dari pikiran manusia. Argumen Anselmus didasarkan pada asumsi bahwa realitas (esse in re) jauh lebih besar dari pikiran (esse in intelectu). ${ }^{44}$ Jikalau Tuhan adalah yang terbesar tetapi hanya sebagai esse in intelectu, maka konsep yang ditawarkan oleh Anselmus adalah sebuah kontradiksi. Oleh karena itu,

$39 \mathrm{KrV}$ B 669.

40 Lih. Wolfgang Röd, Der Gott der reinen Vernunft, S. 132.

$41 \mathrm{KrV} \mathrm{B} 630$.

42 Anselm von Canterbury, Proslogion, Latein-Deutsch Ausgabe, ed. Franciscus Salesius Smitt (Stuttgart-Bad Cannstatt: Frommann 1962,), S. 84.

43 Terjemahan ini mengacu pada terjemahan dari Simon P. L. Tjahjadi. Simon P. L. Tjahjadi, Tuhan para Filsuf dan Ilmuwan: Dari Descartes sampai Whitehead, hlm. 25.

44 "Et certe id quo maius nihil cogitari nequit, non potest esse soli in intellectu. Si enim vel in solo intellectu est potest cogitari esse et in re; quod maius est." Penekanan dari penulis. Anselm von Canterbury, Proslogion, S. 84 . 
Tuhan adalah yang terbesar tidak hanya sebagai esse in intelectu, tetapi juga esse in re. Dengan kata lain, konsep Tuhan sebagai yang terbesar tidak mungkin jika tidak dibarengi dengan eksistensi sebagai sebuah keharusan mutlak. Eksistensi merupakan sebuah keharusan mutlak (Notwendigkeit der Sache) dan ini tidak sekadar keharusan logis (Notwendigkeit des Denkens) karena eksistensi merupakan bagian tidak terpisahkan dari hakekat Tuhan. ${ }^{45}$ Dalam tradisi rasionalisme, sebuah konsep bukanlah hasil rekaan (Vorstelung) pikiran manusia. Sebuah konsep selalu dilatarbelakangi sebuah penemuan (Vorfindung) akan substansi. Setiap konsep memiliki intensionalitas terhadap sesuatu di luar pikiran. Ada adalah horizon dari pikiran manusia. Dengan kata lain, manusia hanya dapar berpikir tentang apa yang ada. Inilah dalil dasar dari rasionalisme. Oleh karena itu, pembuktian model a priori yang ditawarkan oleh Anselmus mudah diterima di kalangan rasionalisme.

Descartes merumuskan kembali pembuktian ontologis Anselm dengan menelaah Tuhan sebagai "yang paling sempurna"46 (ens summe perfectisimum) di hadapan manusia sebagai mahkluk yang tidak sempurna. Kesempurnaan merupakan sebuah asumsi yang mendahului ketidaksempurnaan. Ketidaksempurnaan bukanlah negasi total dari kesempurnaan. Descartes menegaskan bahwa persinggungan dengan sosok yang sempurna merupakan ide bawaan dan ini merupakan pengetahuan yang terang benderang. ${ }^{47}$

Bagaimana Descartes membuktikan eksistensi Tuhan dengan menggunakan konsep ens summe perfectissimum? Descartes menekankan bahwa eksistensi merupakan bagian tidak terpisahkan dari hakekat Tuhan. ${ }^{48}$ Eksistensi sebagai ketentuan dari Tuhan merupakan sebuah keharusan yang besifat mutlak. Jika konsep Tuhan sebagai ens summe

45 Lih. Josef Seifert, Erkenntnis des Vollkommenen: Wege der Vernunft zu Gott (Bonn: Lepanto, 2010), S. 184.

46 Johannes Hirschberger, Geschichte der Philosohie II: Neuzeit und Gegenwart, S. 95.

47 Lih. Wilhelm Weischedel, Der Gott der Philosophen: Grundlegung einer Philosophischen Theologie im Zeitalter des Nihilismus (Berlin: Lambert Schneider, 2013), S.170.

48 Lih. Klaus Müller, Gottes Dasein Denken (Regensburg: Friedrich Pustet, 2001), S. 70. 
perfectissimum tidak dibarengi dengan eksistensi maka akan terjadi sebuah kontradiksi. Eksistensi merupakan bagian tidak terpisahkan dari sebuah kesempurnaan. Eksistensi bersifat analisis ${ }^{49}$ di dalam konsep ens summe perfectissimum.

Kritik terhadap pembuktian ontologis biasanya lebih diarahkan kepada kritik terhadap metode penyimpulan eksistensi secara analisis. Gaunillo, seorang rahib yang hidup sezaman dengan Anselmus telah mengungkapkan penolakannya terhadap model penyimpulan secara analisis dari pembuktian ontologis. ${ }^{50}$ Thomas Aquinas juga mengkritik metode pembuktian ontologis Anselmus. Thomas tidak menolak kesatuan analisis antara eksistensi dan hakikat Tuhan. Akan tetapi Thomas hanya menolak kemungkinan persinggungan secara intuitif terhadap hakekat Tuhan dengan menggunakan akal budi. ${ }^{51}$ Dalam pandangan Thomas, akal budi tidak dapat mengenali secara intuitif hakikat Tuhan tetapi hanya dapat mengenali Tuhan dari akibat yang ditimbulkan-Nya. Oleh karena itu, pembuktian eksistensi Tuhan dalam pandangan Thomas bukanlah pembuktian langsung (unmittelbar), tetapi pembuktian tidak langsung (mittelbar) karena manusia hanya dapat bersinggungan langsung dengan akibat yang ditimbulkan oleh Tuhan dan bukan sumber penyebabnya.

Dalam pandangan Kant, persoalan mendasar pada pembuktian ontologis Descartes adalah penyimpulan eksistensi secara analisis dari konsep Tuhan. ${ }^{52}$ Kant menolak penyimpulan eksistensi secara analisis

49 Istilah analisis dimaksudkan untuk menjelaskan keterkataitan antara subyek dan predikat yang bersifat tautologis atau pengulangan karena secara a priori predikat sudah terkandung di dalam subyek. Di dalam sebuah penyimpulan yang analisis tidak ada hal baru yang didapatkan karena hasil kesimpulan sudah secara tersirat termuat di dalam proposisi awal. Lih. KrV B 9-10.

50 Gaunillo menyindir Anselmus dengan mengungkapkan sebuah kesimpulan akan keharusan keberadaan secara nyata sebuah pulau yang sempurna di suatu tempat hanya berdasarkan atas keberadaannya secara konseptual di dalam pikiran. Lih. Josef Seifert, Erkenntnis des Vollkommenen: Wege der Vernunft zu Gott, SS. 191-192.

51 Lih. Josef Seifert, Gott als Gottesbeweis: Eine phänomenologische Neubegründung des ontologischen Arguments, (Heidelberg: Universitätverlag Winter, 2000), SS. 327-329.

52 Lih. Wolfgang Röd, Der Gott der reinen Vernunft, S. 153. 
meskipun tidak menolak keternalaran atau kelogisan dari konsep Tuhan. Sebenarnya, Kant menolak paham dasar rasionalisme yang menyatakan bahwa status keternalaran sebagai ada (Sein). Pembuktian ontologis dibangun atas dasar ini. Bagi Kant, keternalaran hanya merupakan sebuah keharusan logis dan tidak serta merta merupakan sebuah keharusan mutlak. Dari keharusan logis tidak serta merta dapat disimpulkan sebuah eksistensi. Pemisahan antara Sein dan Denken terlihat jelas di sini, dan inilah perbedaan mendasar filsafat Kant dengan rasionalisme.

Kant menolak penyimpulan eksistensi secara konseptual analisis dan Kant mengajukan tesis bahwa "Sein jelas-jelas bukanlah predikat real." 53 Untuk memahami tesis Kant ini, terlebih dahulu harus diperjelas arti dari kata real dalam pemahaman Kant. Menurut Martin Heidegger, istilah real yang digunakan oleh Kant tidak ekuivalen dengan istilah nyata (wirklich) atau aktual, tetapi lebih berarti substansialitas (Sachhaltigkeit) yang terkandung di dalam sebuah subyek. ${ }^{54}$ Dalam bahasa Skolastik, istilah real ekuivalen dengan keapaan (quiditas). Pemahaman Kant lebih dekat dekat pemahaman skolastik. Predikat real adalah predikat yang konstitutif bagi keaapaan sebuah subyek dan karenanya subyek tersebut berbeda dengan subyek yang lain. ${ }^{55}$ Predikat real adalah ketentuan yang konstitutif terhadap keapaan dari sebuah subyek. Dengan kata lain, predikat real adalah ketentuan yang intrinsik semacam property atau atribut dari keapaan sebuah subyek. Eksistensi tidak dapat diperlakukan sebagai sebuah atribut yang melekat di dalam sebuah subyek dan oleh karenanya eksistensi tidak dapat disimpulkan secara konseptual analisis. Penolakan terhadap penyimpulan eksistensi secara konseptual analisis merupakan kritik terhadap premis dasar dari pembuktian ontologis. ${ }^{56}$ Kesahihan

$53 \mathrm{KrV}$ B 626. Penekanan yang ditulis italic berasal dari penulis.

54 Martin Heidegger, Kants These über das Sein (Frankfurt am Main: Vittorio Klostermann, 1963), S. 10.

55 Lih. Marco Giovanelli, Reality and Negation-Kant's Principle of Anticipation of Perception: An Investigation of its Impact on the Post-Kantiane Debate (Dordrecht-Heidelberg-LondonNew York: Springer 2010), p. 22.

56 Lih. Dieter Henrich, Der ontologische Gottesbeweis (Tübingen: J.C.B. Mohr, 1960), S. 142. 
penyimpulan eksistensi analisis hanya dimungkinkan jika eksistensi sudah secara a priori tercakup dalam hakekat Tuhan. Eksistensi sebagai sebuah kententuan bukanlah aspek formal tetapi aspek material dari sebuah pengetahuan. Karena bukan aspek formal, eksistensi tidak dapat dibuktikan secara konseptual. Konsep yang dihasilkan oleh nalar merupakan bagian dari ranah formal. Keternalaran tidak dapat dijadikan sebuah landasan untuk menegasan eksistensi karena keternalaran berada di dalam ranah formal dan bukan ranah material. Keternalaran konsep ens realissimum dan ens necessarium tidak dapat dijadikan pembuktian eksistensi.

Eksistensi bukanlah persoalan isi (intention) yang terkandung di dalam sebuah konsep. ${ }^{57}$ Eksistensi tidak menambah sedikitpun terhadap isi sebuah konsep. Kant menggunakan perbandingan antara uang seratus taler $^{58}$ yang ada secara nyata dan yang ada sebagai sebuah possibilitas (baca: dalam pikiran): “Dengan demikian, kenyataan sama sekali tidak melebihi dari apa yang hanya sekedar sebuah posibilitas. Kenyatan uang seratus taler sedikitpun tidak melebihi possibilitas uang seratus taler." 59 Pernyataan ini merupakan bantahan terhadap asumsi dasar pembuktian ontologis. Keharusan eksistensi Tuhan disimpulkan karena kenyatan (esse in re) adalah lebih besar dari apa yang dipikirkan (esse in intellectu). Bagi Kant, eksistensi tidak menambah sedikitpun terhadap isi sebuah konsep. Dengan kata lain esse in re bernilai sama dengan esse in intellectu.

Bagaimana Kant merumuskan kesahihan penyimpulan eksistensi? Eksistensi tidak dapat disimpulkan secara analisis a priori, tetapi disimpulkan secara sintesis ${ }^{60}$ : “Obyek sebagai sebuah kenyataan sama sekali tidak termuat secara analisis di dalam sebuah konsep, tetapi melengkapi

57 Lih. Wolfgang Röd, Der Gott der reinen Vernunft, S. 157.

58 Taler adalah uang logam yang terbuah dari perak. Uang logam ini digunakan sebagai alat pembayaran di Jerman dari abad 15 sampai abad 19.

$59 \mathrm{KrV}$ В 627.

60 Penyimpulan sintesis merupakan penyimpulan yang menambahkan hal baru. Di dalam relasi antara subyek dan presikat, sifat sintesis muncul seandainya predikat tidak termuat secara a priori di dalam sebuah subyek. Relasi sintesis tidak bersifat tautologis dan biasanya bersifat a posteriori. Lih. KrV B 9- 11. 
secara sintesis, tanpa harus mengatakan bahwa seratus taler yang dipikirkan tidak sedikitpun bertambah ketika menjadi Sein di luar konsep." ${ }^{161}$ Eksistensi adalah sebuah ketentuan yang tidak termuat secara konseptual analisis di dalam sebuah subyek, tetapi berasal dari luar subyek dan eksistensi tidak menambah sedikitpun isi atau substansialitas subyek. Eksistensi bukanlah ketentuan intrinsik di dalam subyek.

Selain menuntut penyimpulan secara sintesis, Kant juga mengajukan ketentuan penyimpulan secara a posteriori:

Aku berpikir akan sosok yang merupakan realitas tertinggi (tanpa cela), tetaplah selalu muncul pertanyaan, apakah sosok tersebut ada atau tidak. Karena meskipun di dalam konsep termuat segala posibilitas isi yang melekati subyek tanpa cela sedikitpun, tetaplah ada yang kurang... yaitu bahwa pengetahua akan obyek juga harus dimungkinkan secara a posteriori.62

Eksistensi adalah penyimpulan yang harus dapat ditegaskan secara a posteriori. Tampaknya penyimpulan secara sintesis a posteriori menyiratkan nuansa empiris. Menganggap Kant terjatuh ke dalam empirisme adalah sebuah pandangan yang tidak tepat. Perlu diingat bahwa Kant mengadopsi secara parsial baik paham dasar empirisme maupun rasionalisme di dalam filsafat transendental. Kriteria sintesis a posteriori hanya merupakan salah satu prasyarat dari pernyataan eksistensi. Sayang sekali, Kant tidak memberikan penjelasan yang memadai pada bagian ini. Dengan memasukkan kriteria sintesis a posteriori sebagai salah satu kriteria sebuah pernyataan eksistensi, Kant hanya ingin menegaskan penolakannya kepada model penyimpulan analisis a priori. ${ }^{3}$ Kant hanya menyinggung secara singkat bahwa eksistensi juga harus dapat ditegaskan secara a posteriori dari pengalaman inderawi.

Ketiadaan intuisi yang bersifat inderawi berimplikasi pada ketidakmungkinan penyimpulan secara sintesis a posteriori. Eksistensi bukanlah

$61 \mathrm{KrV} \mathrm{B} 627$.

$62 \mathrm{KrV}$ B 628.

63 Lih. Wolfgang Röd, Der Gott der reinen Vernunft, S. 154. 
predikat yang dapat disimpulkan secara analisis dari konsep Tuhan. Dengan demikian, konsep hanya sekedar rekaan (Vorstellung) yang diciptakan oleh pikiran dan aktualitas dari konsep bukanlah sebuah keharusan mutlak. Putusan akan eksistensi akhirnya harus memenuhi aspek material yang disediakan oleh pengalaman inderawi. Karena ketiadaan aspek material, Kant tidak memberi penegasan terhadap eksistensi Tuhan. Kant mengambangkan putusan akan eksistensi Tuhan.

\section{PENUTUP}

Filsafat transendental menjadikan hubungan antara keternalaran dan ada menjadi renggang. Bahkan pemahaman akan ada mengalami penyempitan jika harus memasukkan unsur material yang disediakan oleh pengalaman inderawi. Di dalam Kritik Kant terhadap pembuktian ontologis terlihat jelas dikotomi antara ada dan keternalaran. Inilah yang menjadi dasar dari penulis untuk mengatakan bahwa profile filsafat transendental menjadi transparan di dalam kritik Kant terhadap pembuktian ontologis. Filsafat transendental mengadopsi secara parsial baik paham dasar rasionalisme maupun empirime. Dikotomi antara ada dan keternalaran dipicu oleh pengadopsian secara parsial paham dasar rasionalisme dan empirisme. Dikotomi antara ada dan keternalaran sebenarnya juga membebani filsafat Ketuhanan Kant di dalam ranah praktis. Dikotomi ini juga akhirnya berujung pada pengambangan putusan eksistensi di dalam filsafat praktis. Di dalam tulisan ini penulis hanya membatasi pembahasan pada filsafat teoretis.

Bagi Kant, ketersediaan pengalaman inderawi merupakan unsur material dalam sebuah pengetahuan. Tanpa adanya unsur material, hasil dari tindakan berpikir bukanlah sebuah pengetahuan tetapi hanya sebuah ide regulatif yang tidak mengharuskan sebuah kepastian eksistensi. Dalam filsafat teoritis, Kant memperlakukan Tuhan bukan sebagai obyek yang berada di luar pikiran manusia, tetapi hanya sebagai sebuah ide regulatif yang secara fungsional dibutuhkan oleh nalar untuk menciptakan sebuah kesatuan total dari pengetahuan. Oleh karena itu, konsep Tuhan hanya sekedar konsep heuristik. Dengan kata lain, sebagai sebuah 
konsep Tuhan tidak memiliki intensionalitas di luar pikiran manusia. Model pemikiran Kant berbeda dengan alam pemikiran Yunani. Dalam alam pemikiran Yunani, pikiran (noein) tidak sekadar hanya merekareka (vorstellen), tetapi secara intuitif terarah kepada obyek (Gegenstand) yang berada di luar subyek. Memang ada faktor intuisi seperti halya pemikiran Kant di dalam sebuah pengetahuan. Akan tetapi, intuisi di dalam pemikiran Yunani tidak bersifat inderawi. Berpikir bukanlah hanya sekedar proses mental yang tertutup di dalam diri subyek dan bagi filsuf Yunani tindakan berpikir bersifat intentional. ${ }^{64}$ Oleh karena itu, konsep bukanlah semata-mata produk pikiran tetapi secara a priori memiliki intensionalitas. Model pendekatan secara dikotomis yang ditawarkan oleh Kant menghilangkan sifat intensionalitas dari konsep.

Dalam ranah teoretis, status Tuhan adalah transendental dan bukan transenden. Implikasi dari perubahan status ini adalah bahwa Tuhan tidak lagi merupakan sebuah substansi yang berada di luar pikiran manusia. Tuhan hanya sekadar ide regulatif yang dikontstruksikan atau diproyeksikan oleh akal budi manusia untuk memenuhi kebutuhan akan kesatuan sebuah pengetahuan. Konsep Tuhan dimunculkan oleh nalar untuk memenuhi kebutuhan mutlak akan kesatuan pengetahuan. Di satu sisi, pendasaran rasionalitas akan konsep Tuhan adalah hal yang patut diterima dengan tangan terbuka. Akan tetapi, pengaburan penegasan akan eksistensi Tuhan, meninggalkan sebuah persoalan terutama bagi teologi.

\section{DAFTAR RUJUKAN}

von Canterbury, Anselm. Proslogion (edisi Latin-Jerman). Ed. Franciscus Salesius Smitt. Stutgart-Bad Cannstatt: Frommann, 1962.

Gabriel, Gottfried. Grundprobleme der Erkenntnistheorie: Vom Descartes $z u$ Wittgenstein Paderborn: Schöningh, 2008.

64 Lih. Wolfgang Schadewaldt, Die Anfang der Philosophie bei den Griechen: Die Vorsokratischer und ihre Vorausetzungen (Frankfurt am Main: Suhrkamp, 1978), S. 320. 
Giovanelli, Marco. Reality and Negation - Kant's Principle of Anticipation of Perception: An Investigation of its Impact on the Post-Kantian Debate. Dordrecht-Heidelberg-London-NewYork: Springer, 2010.

Heidegger, Martin. Kants These über das Sein. Frankfurt am Main: Vittorio Klostermann, 1963.

Heinrich, Dieter. Der ontologische Gottesbeweis. Tübingen: J.C.B. Mohr, 1960.

Hirschberger, Johannes. Geschichte der Philosohie II: Neuzeit und Gegenwart. Freiburg: Herder, 1952.

Höffe, Otfried. Kants Kritik der reinen Vernunft: Die Grundlegung der modernen Philosophie, München: C.H. Beck, 2011.

Huber, Herbert. "Kants Idealismus und dessen grundsätzliche Überwindung durch Hegel," Theologie und Philosophie 59 (1984): 39-65.

Irrlitz, Gerd. Kant Handbuch: Leben und Werke. Stuttgart: J.B. Metzler, 2010.

Jasper, Karl. Die großen Philosophen. München \& Zürich: Piper, 2012.

Kant, Immanuel. Werke in zehn Bänden: Kritik der reinen Vernunft (Band III \& IV). Ed. Wilhelm Weischedel. Darmstadt: Wissenschaftliche Buchgesellschaft, 1983.

Kaulbach, Friedrich. Immanuel Kant. Berlin-New York: de Gruyter, 1982.

Müller, Klaus. Gottes Dasein Denken. Regensburg: Friedrich Pustet, 2001.

Ricken, Friedo. "Von der Unentbehrlichkeit der transzendentalen Theologie: Zum Ideal der reinen Vernunft." In Kants Grundlegung einer kritischen Metaphysik: Eine Einführung in die Kritik der reinen Vernunft. Ed. Norbert Fischer. Hamburg: Felix Meiner, 2010.

Röd, Wolfgang. Der Gott der reinen Vernunft: Ontologischer Gottesbeweis und rationalistische Philosophie. München: C.H. Beck, 2009.

Sala, Giovanni B. "Die Gottesfrage in den Schriften Kants." Zeitschrift der katholische Theologie 123 (2001): 143-171. 1990. . Kant und die Frage nach Gott. Berlin-New York: de Gruyter,

Schadewaldt, Wolfgang. Der Anfang der Philosophie bei den Griechen: Die Vorsokratischer und ihre Vorausetzungen. Frankfurt am Main: Suhrkamp, 1978. 
Schupp, Franz. Geschichte der Philosophie im Überblick, Bd.3: Neuzeit. Hamburg: Felix Meiner, 2003.

Seidl, Horst. Sein und Bewusstsein: Erörterungen zur Erkenntnislehre und Metaphysik in einer Gegenüberstellung von Aristoteles und Kant. Hildesheim-Zürich-New York: 2001.

Seifert, Josef. Erkenntnis des Vollkommenen: Wege der Vernunft zu Gott. Bonn: Lepanto, 2010.

. Gott als Gottesbeweis: Eine phänomenologische Neubegründung des ontologischen Arguments. Heidelberg: Universitätverlag Winter, 2000.

Tjahjadi, Simon P:L. Tuhan Para Filsuf dan Ilmuwan: Dari Descartes sampai Whitehead. Kanisius: Yogyakarta, 2007.

Weischedel, Wilhelm. Der Gott der Philosophen: Grundlegung einer Philosophischen Theologie im Zeitalter des Nihilismus. Berlin: Lambert Schneider, 2013. 